Doi: $10.4274 /$ vhd.91886

Viral Hepatitis Journal 2017;23(1):1-5

\title{
Current Treatment Approach in Acute Hepatitis C Infection
}

\author{
Akut Hepatit C Enfeksiyonunda Güncel Tedavi Yaklașımı
}

\author{
Rahmet GÜNER, Bircan KAYAASLAN \\ Yıldırım Beyazıt University Faculty of Medicine, Department of Infectious Disease and Clinical Microbiology, Ankara, Turkey
}

\begin{abstract}
Acute hepatitis $\mathrm{C}$ virus (HCV) infection has an asymptomatic course in most patients. There is no sufficient data regarding its epidemiological features. Recent advances in the treatment of chronic HCV infection have led also to discuss on acute HCV treatment. The possibility of spontaneous clearance, absence of reduction in response rates with delayed treatment, and being curable easily with new directly acting agents brought interferonfree treatment to the agenda. Current guidelines made some changes in the recommendations for optimal duration of treatment and treatment options for acute HCV infection. We aimed to review the treatment of acute $\mathrm{HCV}$ infection in the light of current data. Keywords: Acute hepatitis C, spontaneous clearance, current treatment approach, interferon-free treatments
\end{abstract}

\section{ÖZ}

Akut Hepatit C virüs (HCV) enfeksiyonu hastaların çoğunda asemptomatik seyreder. Epidemiyolojik özellikleri ile ilgili veriler yetersizdir. Kronik HCV enfeksiyonunun tedavisinde yaşanan yeni gelişmeler, akut HCV tedavisinin de tartışılmasına neden olmuştur. Spontan klirens gelişme intimali, gecikmiş tedavi ile yanıt oranlarında azalma olmaması ve yeni direk etkili antiviraller ile enfeksiyonun kolaylıkla tedavi edilebilmesi interferonsuz tedavi rejimlerini gündeme getirmiştir. Güncel kılavuzlar akut HCV enfeksiyonun tedavi süresi ve seçenekleri ile ilgili birtakım güncellemeler yapmıştır. Bu makalede, akut HCV enfeksiyonunun tedavisinin güncel veriler ışı̆̆ında gözden geçirilmesi amaçlanmıştır.

Anahtar Kelimeler: Akut hepatit $\mathrm{C}$, spontan klirens, güncel tedaviler, interferonsuz tedaviler

Guner R, Kayaaslan B. Current Treatment Approach in Acute Hepatitis C Infection. 2017;23:1-5.

\section{Introduction}

Hepatitis $\mathrm{C}$ virus $(\mathrm{HCV})$ infection is a global health problem that causes chronic liver disease (1). Acute HCV infection is defined as initial six months of hepatitis $\mathrm{C}$ infection after exposure to the virus. It is usually asymptomatic and rarely causes lifethreatening disease. It is difficult to diagnose since the infection is usually asymptomatic. The epidemiological data on acute HCV infection are mostly based on chronic HCV infection $(2,3)$. There is no sufficient epidemiological data in our country, as in all over the world. Achieving high rates of sustained virologic response (SVR) with directly acting antivirals (DAAs) in chronic hepatitis C infection necessitated a rethinking of acute hepatitis $C$ treatment. Optimal treatment options and duration of treatment are still not standardized.

Successful treatment of acute HCV infection in high-risk populations, especially in men who have sex with men and intravenous (IV) drug users is very important for the prevention of transmission in population $(4,5,6)$. In the natural course of acute $\mathrm{HCV}$ infection, most patients are asymptomatic. Only $10-15 \%$ of patients are symptomatic (Figure 1). Jaundice occurs in less than $2 \%$ of cases. Fatigue, nausea, and right upper quadrant pain may be seen. The disease continues 2 to 12 weeks in symptomatic patients. Fulminant hepatitis is rarely seen, especially in patients with an underlying chronic liver disease and hepatitis B co-infection (7).

There is no test defined for the diagnosis of acute HCV infection. Acute HCV infection is diagnosed by anti-HCV seroconversion following possible exposure, elevation of liver enzymes and elimination of other acute liver diseases. The development of anti$\mathrm{HCV}$ seroconversion in patients previously known as seronegative is a valid test for the diagnosis of acute infection. Acute HCV infection is usually defined in high-risk populations such as healthcare workers and IV drug users. In clinically high suspicion, definite diagnosis can be made with a positive HCV RNA in anti$\mathrm{HCV}$-negative patients and anti-HCV seroconversion in the follow-

Address for Correspondence: Rahmet Güner MD, Yıldırım Beyazıt University Faculty of Medicine, Department of Infectious Disease and Clinical Microbiology, Ankara, Turkey Phone: +90 31229125 25-4867 E-mail: rahmetguner@yahoo.com Received: 10.04.2017 Accepted: 23.04.2017

${ }^{\circ}$ Copyright 2017 by Viral Hepatitis Society / Viral Hepatitis Journal published by Galenos Publishing House. 
up. The algorithms to be followed for diagnostic purposes in postexposure period are defined in the guidelines (8).

\section{Observation for Spontaneous Clearance}

Expected benefit from treatment in acute HCV infection is prevention of chronicity. A substantial part of acute HCV infection is spontaneous clearance. In their review evaluating 675 patients from 31 studies, Micallef et al. (9) reported that the rate of spontaneous viral clearance was $26 \%$ in acute hepatitis C. The rate of clearance was reported in the range of $20-42 \%$ in these studies. Grebely et al. (10) evaluated the time to spontaneous virologic clearance and factors associated with clearance in the data drawn from

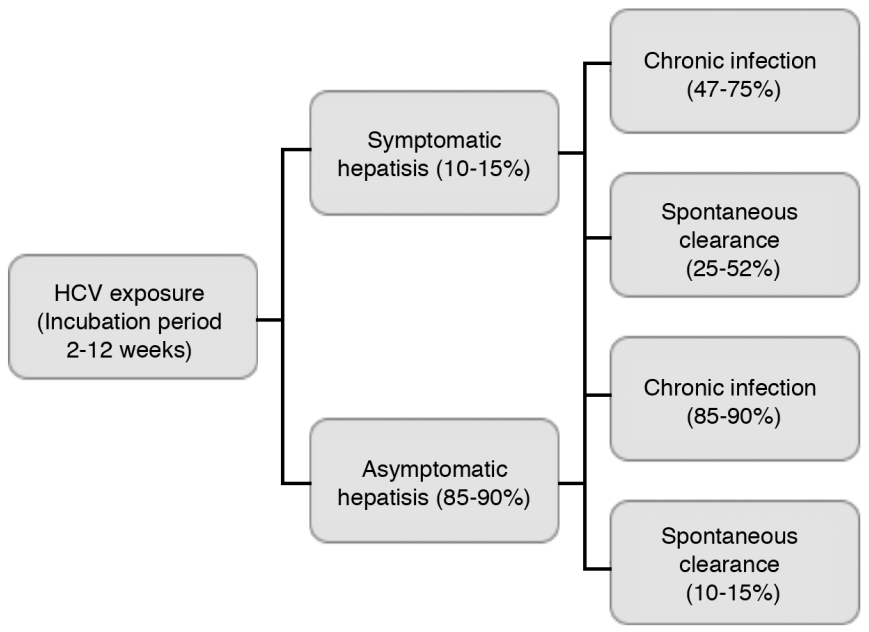

Figure 1. The course of acute hepatitis C virus infection (from Reference 7) international collaboration of nine prospective cohorts. Acute HCV infection in 632 patients from four different European countries was included to the evaluation. Median clearance time was found to be 16.5 weeks. The cumulative clearance rates were reported as $34 \%, 67 \%$ and $83 \%$ at months 3, 6 and 12, respectively. Most of the studies showed that spontaneous clearance usually occurs within the first 6 months of the infection. It has been reported that factors influencing spontaneous clearance positively were being under 30 years of age, female gender, symptomatic infection, IL 28BCC genotype and HCV genotype 1, while independent predictive factors have been determined to be female gender, IL 28 B CC genotype and HCV genotype $1(10,11,12)$. Spontaneous clearance was reported in $46-67 \%$ of symptomatic cases, while no spontaneous clearance observed in asymptomatic patients $(13,14)$. The presence of jaundice may indicate a good immune response resulting in spontaneous clearance. Additionally, spontaneous clearance rates are lower in HIV co-infection (7). HCV infection becomes chronic in most of patients in whom viremia persists at the end of six months.

\section{Interferon-Based Therapies}

Cure rates are high in acute HCV infection with interferon (IFN)-based therapies. Previous guidelines had recommended follow-up for 12 weeks without therapy for spontaneous clearance in acute HCV infection $(5,6)$. It has been shown that SVR is not adversely affected with IFN-based treatments given after a 12-week observation period for spontaneous clearance. Some of important studies' results on IFN-based treatment are summarized in Table 1. In a German study including 44 cases, the patients were treated with IFN for 24 weeks (5MU of IFN alpha-2b daily for 4

\begin{tabular}{|c|c|c|c|}
\hline Ref no. & Number of patients & Treatment regimen and duration & SVR rate (\%) \\
\hline 15 & 44 & $5 \mathrm{MU}$ of IFN alpha-2b daily for 4 weeks and then three times per week for another 20 weeks & 98 \\
\hline 18 & 170 & Peg-IFN alpha $2 b, 12$ weeks & 87 \\
\hline 19 & 132 & Peg-IFN alpha $2 b \pm R B V, 24$ weeks & $90-95$ \\
\hline 20 & 102 & $\begin{array}{l}\text { Peg-IFN alpha 2b, } 8 \text { weeks } \\
\text { Peg-IFN alpha 2b, } 12 \text { weeks } \\
\text { Peg-IFN alpha 2b, } 24 \text { weeks }\end{array}$ & $\begin{array}{l}67.6 \\
82.4 \\
91.2 \\
\end{array}$ \\
\hline 22 & $197^{*}$ & Peg-IFN alpha $2 \mathrm{a} / 2 \mathrm{~b} \pm \mathrm{RBV}, 24$ weeks & 83 \\
\hline 23 & $\begin{array}{l}19 * * \\
48\end{array}$ & $\begin{array}{l}\text { Peg-IFN + RBV + TVR, } 12 \text { weeks } \\
\text { Peg-IFN + RBV, } 24 \text { weeks }\end{array}$ & $\begin{array}{l}84 \\
63\end{array}$ \\
\hline 24 & $\begin{array}{l}57^{* *} \\
73\end{array}$ & $\begin{array}{l}\text { Peg-IFN + RBV + BOC, } 12 \text { weeks } \\
\text { Peg-IFN + RBV, } 24 \text { weeks }\end{array}$ & $\begin{array}{l}86 \\
84\end{array}$ \\
\hline
\end{tabular}


weeks and then three times per week for another 20 weeks). Both at the end of treatment and six month after cessation of treatment, HCV RNA were undetectable in $98 \%$ of cases (15). This is very important study because it shows that standard IFN treatment can prevent chronic HCV infection. In a meta-analysis including 22 studies on 1075 patients who were treated with pegylated (peg)IFN alpha or standard IFN monotherapy, SVR rate was reported to be $78 \%$. The authors reported that the highest SVR rates were achieved in patients whose therapies were initiated after a 12-week of observation period for spontaneous clearance. Based on these findings, they recommended 12 weeks of follow-up for spontaneous clearance without treatment and then initiation of treatment if patients could not achieve spontaneous clearance (16). In another study, SVR was reported to be achieved by treatment with peg-IFN alpha 2b for 24 weeks in $94 \%$ of 16 patients with acute hepatitis $C$ infection, who were still viremic at the end of the 12-week follow-up period (17). Delaying treatment to 8-12 weeks does not lead to a reduction in SVR rates. Initiation of treatment at week 8 or 12 was shown to be resulted in a high SVR rate in a study by Kamal et al. (18) They initiated peg-IFN alpha-2b treatment at three different time points in 129 patients with aacute HCV infection who had no spontaneous clearance at 8 weeks. SVR rates were reported to be $95.3 \%, 93.2 \%$ and $76.6 \%$ with initiating treatment at the weeks 8, 12 and 20, respectively. They reported that the most convenient time to start treatment was 8 to 12 weeks.

In another phase 3 non-inferiority trial conducted as multi-center and randomized study, the efficacy of early and delayed treatment was compared in patients with acute hepatitis C. One group was treated immediately with peg-IFN alpha- $2 b$ for 24 weeks and the other group was prospectively followed for 12 weeks and peg-IFN alpha-2b plus ribavirin treatment was initiated if HCV RNA remained positive. one hundred-seven symptomatic and 25 asymptomatic patients were included in the study. SVR rate was reported as $90 \%$ in symptomatic patients who were treated immediately and $93 \%$ in those given delayed therapy. The authors emphasized that waiting for spontaneous clearance prevents unnecessary treatment, but it would be better to start treatment immediately in patients who cannot be closely followed (19). The study of Kamal et al. (20) is important for comparing the different treatment durations with peg-IFN in acute HCV infection. They reported SVR at the rates of $67.6 \%, 82.4 \%$ and $91.2 \%$ with 8,12 and 24 weeks of peg-IFN treatment, respectively. Age, gender and HCV genotype were found not to be associated with SVR, while rapid virologic response was reported to play an important role in achieving SVR (21).

The other investigated issue is adding ribavirin to the treatment. Data collected from five prospective cohorts of high-risk individuals in Australia, Canada, Germany and the United States provides important data regarding 237 acute HCV patients. Based on this study, the duration of infection, baseline HCV RNA level of $<400,000 \mathrm{lU} / \mathrm{mL}$, IL 28B CC genotype and $\geq 40$ years of age were determined as independent predictive factors in terms of achieving SVR in patients with HCV mono-infection. Combination therapy, HCV genotype, asymptomatic infection and gender were not found as an independent risk factor for SVR (22). Therefore, it can be said that the addition of ribavirin to the combination in acute $\mathrm{HCV}$ infection is not beneficial. The other choice is the addition of protease inhibitor to peg-IFN + ribavirin combination. Data obtained through the New York acute hepatitis C Surveillance Network showed that a 12-week treatment course with a combination of peg-IFN + ribavirin + telaprevir achieved SVR in 84\% of 19 human immunodeficiency virus (HIV)-infected men with acute genotype $1 \mathrm{HCV}$ infection (23). SVR was also detected at the rate of $78 \%$ with triple combination treatment with boceprevir (BOC) in the similar patient population and SVR rate was reported to be $95 \%$ in the group who achieved rapid virologic response (24). As it has become clear according to the studies, high cure rates were achieved with IFN-based therapies in acute HCV patients who did not develop spontaneous clearance. Today, when DAAs have been successfully used in chronic hepatitis C therapy without IFN, the European Association for the Study of the Liver (EASL) guideline for HCV infection emphasized that the optimal time for starting treatment in acute HCV infection is not clear and ALT elevation may be the starting point of ideal treatment independent of clinical manifestations (25). The American Association for the Study of Liver Diseases (AASLD) guideline for hepatitis $C$ recommends regular HCV RNA monitoring every 4 to 8 weeks until 6-12 months after the diagnosis of acute HCV infection without initiating treatment (26). In addition, it was emphasized that trying to determine the route of the virus exposure during the follow-up period, and the counseling for the behaviors associated with transmission risk should be kept in mind. Especially, it should not be forgotten that IV drug users have a high risk for HCV transmission. Acute hepatitis $\mathrm{C}$ patients should also be warned about avoiding hepatotoxic drugs $(25,26)$. The AASLD guideline recommends an observation period of minimum 12 weeks for spontaneous clearance before treatment in patients who cannot wait 6-12 months, and educating the patients who decided to wait 6-12 months regarding rules in chronic HCV infection (26).

\section{Interferon-Free Direct Acting Antiviral Combination Therapies}

There are a limited number of studies regarding DAAs treatment in acute hepatitis $\mathrm{C}$ and some of them are in the form of report. The HepNet Acute HCV-IV Study aimed to investigate the effectiveness of the 6-week sofosbuvir/ledipasvir combination in genotype 1 acute HCV mono-infected patients. In the cohort including 20 patients, SVR12 was achieved in all patients. It was noted that while the virologic response was found to be slower in patients with high baseline HCV RNA levels, ALT and bilirubin levels rapidly returned to normal in majority of patients (27). In the SLAM-C Study, the effectiveness of the 4-week sofosbuvir/ledipasvir and the 8-week sofosbuvir/simeprevir treatments were evaluated in 24 patients. According to per protocol analysis, SVR12 was achieved in all patients in both groups (28). In a study by Rockstroh et al. (29), sofosbuvir/ledipasvir combination was used for 6 weeks to treat genotype 1 or 4 acute hepatitis $C$ patients co-infected with HIV. The study data has yet to reach SVR4 results. SVR4 was achieved in $85 \%$ of patients and recurrence was observed in $15 \%$. The researchers reported a strong association between baseline HCV RNA levels and response to treatment. SVR4 was achieved in all patients with a HCV RNA level of $<9$ million IU/mL. SVR12 results are not yet available in the study. The SWIFT-C Study investigating sofosbuvir/ribavirin combination therapy for 12 weeks 
in HIV-coinfected acute hepatitis $\mathrm{C}$ patients reported high relapse rates (30). Upon this, the other 8-week cohort of this study was changed to sofosbuvir/ledipasvir treatment. In the DARE C Study, 19 patients (14 coinfected with HIV) were treated with sofosbuvir and ribavirin combination for 6 weeks. At the end of treatment, HCV RNA became undetectable in $89 \%$ of patients $(n=17)$. However, SVR4 and SVR12 rates were only 42\% (8) and 32\% (6), respectively. No response to treatment (2), posttreatment relapse (9), reinfection (1), and loss to follow-up (1) were the reasons for treatment failure. The authors emphasized that 6 weeks of sofosbuvir/ribavirin combination have a suboptimal efficacy for acute HCV treatment (4). The EASL has listed the recommended treatment options in the current guidelines for use in acute $\mathrm{HCV}$ infection as shown in Table 2 (25).

Table 2. The European Association for the Study of the Liver treatment recommendation in acute hepatitis $\mathrm{C}$ infection (Transferred exactly from European Association for the Study of the Liver)

Patients with acute hepatitis $C$ should be treated with a combination of sofosbuvir and ledipasvir (genotypes 1, 4, 5 and $6)$, a combination of sofosbuvir and velpatasvir (all genotypes), or a combination of sofosbuvir and daclatasvir (all genotypes) for 8 weeks without ribavirin (B1).

Patients with acute hepatitis $C$ and HIV coinfection and/or a baseline HCV RNA level $>1$ million $\mathrm{IU} / \mathrm{mL}(6.0 \log \mathrm{IU} / \mathrm{mL}$ ) may need to be treated 12 weeks with the same combination regimens (B2).

SVR should be assessed at 12 and 24 weeks' post-treatment, because late relapses have been reported (B2).

HCV: Hepatitis C virus, HIV: Human immunodeficiency virus, SVR: Sustained virologic response

\section{Conclusion}

Case series with a small number of patients show that direct antivirals, especially sofosbuvir/ledipasvir combination, can be successfully used in acute HCV genotype 1, 4, 5, 6 infections. However, high success rates in the treatment of chronic HCV infection and high spontaneous clearance rates indicate that the treatment can be postponed with determining the eligible patient population and a good counseling before treatment.

\section{Ethics}

Peer-review: Internally peer-reviewed.

\section{Authorship Contributions}

Surgical and Medical Practices: R.G., B.K., Concept: R.G., B.K., Design: R.G., B.K., Data Collection or Processing: R.G., Analysis or Interpretation: R.G., Literature Search: R.G., Writing: R.G., B.K.

Conflict of Interest: No conflict of interest was declared by the authors.

Financial Disclosure: The authors declared that this study received no financial support.

\section{References}

1. Wilkins T, Akhtar M, Gititu E, Jalluri C, Ramirez J. Diagnosis and Management of Hepatitis C. Am Fam Physician. 2015;91:835842.
2. Sharma SA, Feld JJ. Acute hepatitis C: management in the rapidly evolving world of HCV. Curr Gastroenterol Rep. 2014;16:371.

3. Kamal SM. Acute hepatitis C: Prospects and challenges. World J Gastroenterol. 2007;13:6455-6457.

4. Martinello M, Gane E, Hellard M, Sasadeusz J, Shaw D, Petoumenos K, Applegate T, Grebely J, Maire L, Marks P, Dore GJ, Matthews GV. Sofosbuvir and ribavirin for 6 weeks is not effective among people with recent hepatitis $C$ virus infection: The DARE-C II study. Hepatology. 2016;64:1911-1921.

5. European Association for Study of Liver. EASL Recommendations on Treatment of Hepatitis C 2015. J Hepatol. 2015;63:199-236.

6. AASLD/IDSA HCV Guidance Panel. Hepatitis C guidance: AASLDIDSA recommendations for testing, managing, and treating adults infected with hepatitis C virus. Hepatology. 2015;62:932-954.

7. Maheshwari A, Ray S, Thuluvath PJ. Acute hepatitis C. Lancet. 2008;372:321-332.

8. U.S. Public Health Service. Updated U.S. Public Health Service Guidelines for the Management of Occupational Exposures to $\mathrm{HBV}, \mathrm{HCV}$, and HIV and Recommendations for Postexposure Prophylaxis. MMWR Recomm Rep. 2001;50:1-52.

9. Micallef JM, Kaldor JM, Dore GJ. Spontaneous viral clearance following acute hepatitis C infection: a systematic review of longitudinal studies. J Viral Hepat. 2006;13:34-41.

10. Grebely J, Page K, Sacks-Davis R, van der Loeff MS, Rice TM, Bruneau J, Morris MD, Hajarizadeh B, Amin J, Cox AL, Kim AY, McGovern BH, Schinkel J, George J, Shoukry NH, Lauer GM, Maher L, Lloyd AR, Hellard M, Dore GJ, Prins M; InC3 Study Group. The effects of female sex, viral genotype, and IL28B genotype on spontaneous clearance of acute hepatitis $C$ virus infection. Hepatology. 2014;59:109-120.

11. Kamal SM. Acute hepatitis C: a systematic review. Am J Gastroenterol. 2008;103:1283-1297.

12. Mosley JW, Operskalski EA, Tobler LH, Buskell ZJ, Andrews WW, Phelps B, Dockter J, Giachetti C, Seeff LB, Busch MP; Transfusiontransmitted Viruses Study and Retrovirus Epidemiology Donor Study Groups. The course of hepatitis C viraemia in transfusion recipients prior to availability of antiviral therapy. J Viral Hepat. 2008; 15:120-128

13. Hofer $H$, Watkins-Riedel $T$, Janata $O$, Penner $E$, Holzmann $H$, Steindl-Munda P, Gangl A, Ferenci P. Spontaneous viral clearance in patients with acute hepatitis $C$ can be predicted by repeated measurements of serum viral load. Hepatology. 2003;37:60-64.

14. Dirchwolf M, Marciano S, Mauro E, Ruf AE, Rezzonico L, Anders M, Chiodi D, Petta NG, Borzi S, Tanno F, Ridruejo E, Barreyro F, Shulman C, Plaza P, Carbonetti R, Tadey L, Schroder T, Fainboim $\mathrm{H}$. Clinical epidemiology of acute hepatitis $\mathrm{C}$ in South America. J Med Virol. 2017:89:276-283.

15. Jaeckel $E$, Cornberg $M$, Wedemeyer $H$, Santantonio $T$, Mayer J, Zankel M, Pastore G, Dietrich M, Trautwein C, Manns MP; German Acute Hepatitis C Therapy Group. Treatment of acute hepatitis C with interferon alfa-2b. N Engl J Med. 2001;345:14521457.

16. Corey KE, Mendez-Navarro J, Gorospe EC, Zheng H, Chung RT. Early treatment improves outcomes in acute hepatitis C virus infection: a meta-analysis. J Viral Hepat. 2010;17:201-207.

17. Santantonio $T$, Fasano M, Sinisi E, Guastadisegni $A$, Casalino $C$, Mazzola M, Francavilla R, Pastore G. Efficacy of a 24-week course of PEG-interferon alpha-2b monotherapy in patients with acute hepatitis C after failure of spontaneous clearance. J Hepatol. 2005;42:329-333

18. Kamal SM, Fouly AE, Kamel RR, Hockenjos B, Al Tawil A, Khalifa KE, He Q, Koziel MJ, El Naggar KM, Rasenack J, Afdhal NH. Peginterferon alfa-2b therapy in acute hepatitis $C$ : impact of onset of therapy on sustained virologic response. Gastroenterology. 2006:130:632-638. 
19. Deterding K, Grüner N, Buggisch P, Wiegand J, Galle PR, Spengler U, Holger Hinrichsen, Thomas Berg, Andrej Potthoff, Nisar Malek, Anika Großhennig, Armin Koch, Helmut Diepolder, Stefan Lüth, Sandra Feyerabend, Maria Christina Jung, Magdalena Rogalska-Taranta, Verena Schlaphoff, Markus Cornberg, Michael P Manns, Heiner Wedemeyer, for The Hep-Net Acute HCV-III Study Group. Delayed versus immediate treatment for patients with acute hepatitis $\mathrm{C}$ : a randomised controlled non-inferiority trial. Lancet Infect Dis. 2013;13:497-506.

20. Kamal SM, Moustafa KN, Chen J, Fehr J, Abdel Moneim A, Khalifa KE, El Gohary LA, Ramy AH, Madwar MA, Rasenack J, Afdhal $\mathrm{NH}$. Duration of peginterferon therapy in acute hepatitis C: a randomized trial. Hepatology. 2006;43:923-931.

21. Santantonio $T$, Fasano $M$, Sagnelli $E$, Tundo $P$, Babudieri $S$, Fabris $P$, Toti M, Di Perri G, Marino N, Pizzigallo E, Angarano G; Acute Hepatitis C Study Group. Acute hepatitis C: a 24-week course of pegylated interferon $\alpha$-2b versus a 12-week course of pegylated interferon $\alpha-2 b$ alone or with ribavirin. Hepatology. 2014;59:2101-2109.

22. Doyle JS, Deterding K, Grebely J, Heiner Wedemeyer, Rachel Sacks-Davis, Tim Spelman, Gail Matthews, Thomas M. Rice, Meghan D. Morris, Barbara H. McGovern, Arthur Y. Kim, Julie Bruneau, Andrew R. Lloyd, Kimberly Page, Michael P. Manns, Margaret E. Hellard, and Gregory J. Dore6, ${ }^{*}$ on behalf of the InC3 Study Group. Response to treatment following recently acquired hepatitis $\mathrm{C}$ virus infection in a multi-centre collaborative cohort. J Viral Hepat. 2015;22:1020-1032.

23. Fierer DS, Dieterich DT, Mullen MP, Branch $A D$, Uriel AJ, Carriero DC, van Seggelen WO, Hijdra RM, Cassagnol DG; New York Acute Hepatitis C Surveillance Network. Telaprevir in the treatment of acute hepatitis $\mathrm{C}$ virus infection in HIV-infected men. Clin Infect Dis. 2014;58:873-879.

24. Hullegie SJ, Claassen MA, van den Berk GE, van der Meer JT, Posthouwer D, Lauw FN, Leyten EM, Koopmans PP, Richter C, van Eeden A, Bierman WF, Newsum AM, Arends JE, Rijnders BJ. Boceprevir, peginterferon and ribavirin for acute hepatitis $C$ in HIV infected patients. J Hepatol. 2016;64:807-812.
25. European Association for the Study of the Liver. Electronic address: easloffice@easloffice.eu. EASL Recommendations on Treatment of Hepatitis C 2016. J Hepatol. 2017;66:153194.

26. Recommendations for Testing, Managing, and Treating Hepatitis C. American Association for the Study of Liver Diseases (AASLD) and the Infectious Diseases Society of America (IDSA). Available from URL: http://live-hcv-guidance-new.gotpantheon.com). [Accessed 2017 Feb 14]

27. Deterding K, Spinner CD, Schott E, Welzel TM, Gerken G, Klinker $H$, Spengler U, Wiegand J, Zur Wiesch JS, Pathil A, Cornberg M, Umgelter A, Zöllner C, Zeuzem S, Papkalla A, Weber K, Hardtke $S$, von der Leyen $H$, Koch $A$, von Witzendorff $D$, Manns MP, Wedemeyer H; HepNet Acute HCV IV Study Group. Ledipasvir plus sofosbuvir fixed-dose combination for 6 weeks in patients with acute hepatitis $\mathrm{C}$ virus genotype 1 monoinfection (HepNet Acute HCV IV): an open-label, single-arm, phase 2 study. Lancet Infect Dis. 2017;17:215-222.

28. Basu PP, Shah NJ, Aloysius MM, Kavali L, Shehi E, Brown Jr RS. Sofosbuvir and Ledipasvir versus Sofosbuvir and Simeprevir Combination Therapy in the Management of Acute Hepatitis C: A Randomized Open Label Prospective Clinical Pilot Study. Slam C Study. J Hepatol. 2016;64(Suppl):806.

29. Rockstroh JK, Bhagani S, Hyland RH, Yun C, Zhang W, Brainard DM, McHutchison JG, Ingiliz P, Lutz T, Nelson M. Ledipasvir/ sofosbuvir for 6 weeks in HIV-infected patients with acute $\mathrm{HCV}$ infection. Conference on Retroviruses and Opportunistic Infections (CROI) 2016; Boston, MA, USA; 2016. Abstract 154LB.

30. Naggie S, Marks KM, Hughes M, Fierer DS, Kim AY, Hollabaugh K, Kiser J, Roa J, Symonds B, Brainard DM, McHutchison JG, Peters MG, Chung RT. Sofosbuvir Plus Ribavirin Without Interferon for Treatment of Acute HCV in HIV-1 Infected Individuals: SWIFT-C. AASLD. 2015:110338. 